Finanse, Rynki Finansowe, Ubezpieczenia nr 4/2017 (88), cz. 2

DOI: $10.18276 /$ frfu.2017.88/2-14

s. $135-144$

\title{
The Importance of Funding Sources to the Scale of Activity of Social Enterprises
}

\author{
Pawel Mikolajczak*
}

\section{Introduction}

The discussion on the possibilities of funding civil activity more and more often stresses the validity of efforts made by non-governmental organisations aiming at commercial activity: the commercial sale of goods and services. Such a way of gaining capital can be defined as the economisation of non-governmental organisations which classifies them in the sector of social enterprises. Growing needs, in broadly understood social domain, and changes in social policy, expressed, among other things, in reducing social aid spending, put pressure on developing commercial strategies by non-governmental organisations to gain funding essential for social mission fulfilment. Aside from human factor, it is financial capital which is a key factor to perform tasks attributed to NGOs.

A commercial activity of social enterprises, as the source of capital contribution, involves activity and resources of various entities which support their social mission. In a traditional approach, social enterprises try to attract attention of private and institutional donators to finance their priorities. The financial and non-financial involvement of donators strongly influences the possibilities and a scale of performed activity. Another source of revenues of social enterprises are public sources gained from national and international funds. A vital role in that respect is played by the EU structural funds.

Numerous researches stress the validity of the economisation of social enterprises regarding the increase of economic stability, self-sufficiency or establishing closer relationships with other entities (Hager, 2001, p. 376-392; Keating, Fischer, Gordon, Greenlee, 2005; Greenlee, 2002, p. 199-210; Carmin 2010, p. 183-202; Carroll, Stater, 2009, p. 947-966; Weber, 2012; Geobey, Weber 2013, p. 124-137; Dees, 1998, p. 54-69). This way they emphasise the need of creation and development of social enterprises.

\footnotetext{
dr Paweł Mikołajczak, Uniwersytet Ekonomiczny w Poznaniu, Wydział Ekonomii, Katedra Pieniądza i Bankowości, 61-875 Poznań, al. Niepodległości 10, e-mail: pawel.mikolajczak@ue.poznan.pl
} 
However, in scientific elaborations, devoted to NGOs marketisation, there is a significant lack of research showing real influence of various financing resources on the scale of their activity. In that respect, the analysis of those dependencies is the main aim of the paper. ANOVA analysis and rankings analysis was used to achieve that goal. Also, other methods including: step regression, interactive trees (Classification and Regression Trees - C\&RT), reinforced trees, MARSplines and neural networks, were used.

\section{The economization of NGOs' activities}

Non-governmental organisation (NGOs) cover a wide range of organisational forms. These are the enterprises which secure a certain form of social work and do not belong to a sector of commercial and governmental entities (Gray, Bebbington, Collison, 2006). The lack of affiliation with the latter is a base to define NGOs (Salamon, Hems, Chinnock, 2000). NGOs are self-governed, independent organizations, of a voluntary character and a tendency to involve their supporters and members in the activities on the basis of common values, interests or concerns. They aim at public benefit and are formally registered by the state (Kilby, 2006, p. 951-963).

As Martens (2002, p. 282) indicates NGOs are formal (professional), independent social organisations which strive for promotion of common goals on the national and international level. Growing needs, in broadly understood social domain, and changes in social policy, expressed in a decrease of social aid spending, put pressure on NGOs to develop commercial strategies to gain financing indispensable to fulfil their social mission (Kerlin, Pollak, 2006), and, at the same time, their "transformation" to social enterprises.

The consideration on the economisation of NGOs must start with an issue of semantics. Polish term "economization" is derived from English economisation. In Polish and foreign literature, we can encounter also other terms, such as marketisation (Simpson, Cheney, 2007, p. 191-222; Dart 2004a, p. 290-310 and 2004b, p. 411-424), commercialization (Dees, 1998, p. 54-69; Eikenberry, Kluever, 2004, p. 132-140) or less frequently a term professionalisation (Stankiewicz, Seiler, 2013, p. 354; Zielińska, 2011, p. 96-104).

In relation to social organisation the term economisation means an attempt to adapt entrepreneurial behaviours to gain sources for realisation of their social mission, which in the face of growing needs in a social domain requires bigger financial inputs (Salamon, 1997). As Calışkan and Callon (2009) indicate, the economisation can be described as a complex process which bases on a precise categorisation of entities which are subject to the economisation. The foundation of this process is to gain the capital from profitable activity which classifies social organisations conducting their own business activity into the sector of social enterprises (Mikołajczak, Czternasty, 2015a, p. 43-52). The activity of NGOs as the entities of social economy is not oriented towards profit which is one of their basic features.

The economisation of social organisations stimulates the creation of economic stability of the organisation which, as Carmin (2010, p. 183-202) states, is vital for NGOs because 
it provides not only the support which enables the activity oriented towards social goals but also the sources to employ workers, buy equipment and keep the posts. It also concerns the changes in the scope of management of organisations, emphasising their enterprising character and self-efficiency (Foster, Bradach, 2005, p. 92-100).

\section{Financing the activity of social enterprises}

Adaptation of entrepreneurial behaviours of gaining the capital for activity of the organisation and entrepreneurial orientation in generating revenues relates to the dualism of NGOs' activity. It refers to the change of functioning formula from non-profit to not-for-profit, i.e. entering the market directly and initiating a business or other form of paid activity. However, NGOs must depend on many different sources of support to fulfil social mission (Froelich, 1999, p. 246-268; Enjolras, 2002; King, 2006; Maier, Meyer, Steinbereithner, 2016, p. 64-86). In turn, among financial premises, another incentive for NGOs to diverse sources of their revenues is a default threat and possibility of revenue drop which were identified as the consequence of the latter. Research showed that NGOs of differentiated revenues are characterised by a stronger financial position compared to those which use only few revenue sources (Chang, Tuckman, 1994, p. 273-290; Keating et al., 2005).

NGOs operating as social enterprises, apart from business revenues, try to attract attention of private and institutional donators to finance their priorities. The financial and non-financial involvement of private and institutional donators supports the opportunities for the activity. Researchers stress that conducting a business activity by social enterprises, on one hand, allows to become more independent of public administration and philanthropy (Dees, 1998, p. 54-69), while on the other, it gives them the opportunity to gain resources from social investors (Geobey, Weber, 2013, p. 124-137). An example of such financing can be Social Impact Investing (SII) which constitute a new class of assets representing a special relation of risk return (O’Donohoe, Leijonhufvud, Saltuk, Bugg-Levine, Brandenburg, 2010) and which have similar properties to "high effectiveness" investments (Brandstetter, Lehner, 2014).

Social enterprises also have numerous opportunities of using public sources. The latter refer to national financing, as well as, international (including EU funds). The EU funding can represent a significant supplement for national resources of social enterprises which are provided via numerous other mechanisms offered earlier by the European Commission within the framework announced in "The Social Business Initiative". It shows that the EU notices a clear need to support social enterprises, which is also reflected in structural funds proposed by the Commission. It concerns the European Social Fund, European Regional Development Fund and Cohesion Fund (Mikołajczak, Czternasty, 2015b, p. 427-428).

Among the researchers there are the voices of criticism. Edward and Hume (1996, p. 969) prove that some NGOs, which are concerned to be social enterprises, by establishing closer relationships with the state within public financing, can improve the scale of activity and supersede smaller organisations. As a consequence, it results in dominations of big entities. 
Moreover, commercial non-governmental organisations, which have access to significant governmental sources, can expand their actions and, at the same time, to decrease their activity in fields which are important from the point of view of benefactors. According to the authors, short-term public subsidies limit the pursuit of commercial and non-commercial NGOs to implement innovations because time and space for reflections on innovative activity within non-governmental organisations yield a drastic decrease in those NGOs which become contractors of requirements of the subsidy.

\section{Data and research methods}

The obtained data came from the Klon/Jawor Association which conducted a research based on a national, representative sample of 3800 NGOs (foundations and associations) in the second and third quarter of 2015. The research, commissioned by the Klon/Jawor Association, was carried out by Millward Brown. The research was conducted on a randomstratified sample of foundations and associations, which was sampled from REGON registry of GUS (Main Statistical Office) (situation as of December 2014), verified basing on the information from KRS (Krajowy Rejestr Sądowy - National Court Register) and the data from bazy.ngo.pl website'

In Poland, there are 17 thousand registered foundations and 86 thousand associations (excluding Volunteer Fire Department). However, only 70 thousand of them are active. Most of the nongovernmental organisations are involved in sport activities, tourism, recreation and hobbies. They constitute the basic scope of activities of $34 \%$ of a total number of organisations.

The percentage of NGOs which are mostly involved in education reaches $15 \%$ of non-governmental sector. The third most numerous group of this sector includes organisations which focus on culture and art - 13\% of analysed NGOs. A smaller number of organisations covers social services, health protection and development.

There were several arguments which persuaded the Author to use the secondary data made available by the Klon/Jawor Association. First and foremost, it enabled to enlarge the sample, its representativeness and the number of observations which led to broader conclusions in the course of conducted statistical analysis. Moreover, using the existing data, combined with own analyses, made it possible to fulfil also different goals than those initial ones which prompted the collection of data. A significant premise of an economic nature of such approach was the cost of research - much lower compared to original research (Frankfort-Nachmias, Nachmias, 2001, p. 321-323).

1 The data on foundations and associations was gathered basing on the interviews. This method used two research techniques: 1) 2975 interviews were conducted using CAPI technique (Computer-assisted personal interviewing; pollster in the field; 2) 825 interviews were carried out using CAWI technique (Computer-assisted web interviewing; online survey). In both cases, the respondents were people fulfilling key functions in organisations. The data was gathered confidentially. Additionally, the report used techniques of preliminary exploratory research of a quality character. Within its framework, in the third quarter of 2014, 24 broadened individual interviews, with employees and leaders of non-governmental institutions, were carried out. 
In the preliminary stage of research, among all non-governmental organisations, those were chosen which determined their revenues, costs and which indicated at least one financing source. Among surveyed entities, 3432 were selected for further analysis. Then, to estimate the operational scale, natural logarithms of NGOs' revenues, obtained in 2014, were calculated. In turn, to statistically check the significant differences between those NGOs which conduct a business activity - social enterprises (the sample of 412 entities was selected, 25 of those entities did not present the revenues in 2014, therefore, for further analysis a sample of 387 NGOs was selected) and do not conduct a business activity, ANOVA analysis was employed within the scale of their functioning.

In the next phase of analysis all NGOs were classified into two categories on the basis of the source of funding (external or internal) which were distinguished in the survey. Analyses of the influence of individual financing sources on the activity scale of selected NGOs were carried out using the regression tasks of the following methods: (step regression, interactive trees (C\&RT), reinforced trees, MARSplines and neural networks). In the next step a ranking of the above mentioned regression methods was made, according to a fit criterion of each function to measure the influence of a given source of financing on the scale of NGO activities among those used in the activities of social enterprises and NGOs not conducting business activity. A ranking was formed from the most significant to the least significant source of funding. The smaller the weight, the bigger the influence of a given financing source on the scale of business. Variables were described as the frequency of individual sources.

\section{Empirical results}

Basing on the results of ANOVA analysis, we can deduce that the scale of NGOs' activity conducting a commercial sale of goods and services (social enterprises) is statistically significantly higher than for those which do not perform such activity. F-statistics of variance analysis reached 347,38 at $p=0,00$. Brown-Forsythe test indicated the homogeneity of variance in tested groups: $p=0,09$.

From the point of view of stimulating the activity of non-earning NGOs, the main financing sources were national, as well as international, public funds. The most significant sources were the EU funds, followed by central government and administration funds, as well as funds coming from Local councils and the European Commission Programmes. Internal and external private financing occurred to be the least important, from the point of view of non-earning NGOs' operational scale. The interesting thing is that such regularity can be observed also in case of sources form individual and institutional private donators. Membership fees are of a very little importance for the scale of activity of those NGOs which are not social enterprises (see table 1). 
Table 1

Ranking of financing resources for NGOs not conducting a business activity

\begin{tabular}{|c|c|c|}
\hline Source of financing & Internal/external & Weight \\
\hline EU funding & external & 3,2 \\
\hline Central government and administration & external & 4,8 \\
\hline Foreign funding (excluding EU) & external & 5,4 \\
\hline Local council & external & 5,8 \\
\hline Programmes of the European Commission & external & 8 \\
\hline Support from other national NGOs & external & 8 \\
\hline Support from other foreign NGOs & external & 8 \\
\hline $\begin{array}{l}\text { Interests, profits from endowment capital, } \\
\text { deposits, shares and stocks }\end{array}$ & internal & 11 \\
\hline Donation from other divisions & external & 11,2 \\
\hline Revenues from $1 \%$ of the income tax & external & 11,4 \\
\hline $\begin{array}{l}\text { Financial and non-financial donations from } \\
\text { private individuals }\end{array}$ & external & 11,8 \\
\hline Membership fees & internal & 12,2 \\
\hline Public fund-raising revenues & external & 12,8 \\
\hline Revenue form assets & internal & 13,2 \\
\hline $\begin{array}{l}\text { Revenue from paid-activity of the third } \\
\text { sector (excluding businesses) }\end{array}$ & internal & 13,2 \\
\hline $\begin{array}{l}\text { Financial and non-financial donations from } \\
\text { institutions, companies }\end{array}$ & external & 13,4 \\
\hline Punitive damages & external & 16,6 \\
\hline
\end{tabular}

Source: own analysis on the basis of a survey data of the Klon/Jawor Association research on "Condition of the third sector in Poland in 2015"; calculations run in STATSTICA 12.

When analysing the ranking of financing sources of non-governmental organisations which can be recognised as social enterprises, we can notice a few interesting dependencies. Similar situation occurs in case of NGOs that do not conduct a business activity, i.e. EU funds are the most important of capital support for those entities, when it comes to the operational scale, as well as foreign public aid. Private sources in a form of revenues from financial and non-financial assets clearly become more and more important (interests, profits from endowment capital, deposits, shares and stocks and revenue from property). However, revenues from paid-activity (sale of goods and services) do not play a key role from the point of view of social enterprises in a form of NGOs. Yet, they are not of no significance. 


\section{Table 2}

Ranking of financing resources of social enterprises (NGOs conducting a business activity)

\begin{tabular}{|c|c|c|}
\hline Source of financing & Internal/external & Weight \\
\hline EU funding & external & 2,2 \\
\hline Programmes of the European Commission & external & 3,6 \\
\hline Foreign funding (excluding EU) & external & 4 \\
\hline $\begin{array}{l}\text { Interests, profits from endowment capital, } \\
\text { deposits, shares and stocks }\end{array}$ & internal & 9,2 \\
\hline Central government and administration & external & 10 \\
\hline Local council & external & 10,6 \\
\hline Revenue from assets & internal & 10,6 \\
\hline Support from other national NGOs & external & 11,4 \\
\hline Support from other foreign NGOs & external & 11,8 \\
\hline Donation from other divisions & external & 12,4 \\
\hline Membership fees & internal & 13 \\
\hline $\begin{array}{l}\text { Revenue from commercial activity (sale } \\
\text { of products and services) }\end{array}$ & internal & 13,2 \\
\hline Public fund-raising revenues & external & 13,8 \\
\hline $\begin{array}{l}\text { Financial and non-financial donations from } \\
\text { institutions, companies }\end{array}$ & external & 14 \\
\hline $\begin{array}{l}\text { Financial and non-financial donations from } \\
\text { private individuals }\end{array}$ & external & 14,8 \\
\hline Revenues from $1 \%$ of the income tax & external & 16,2 \\
\hline Punitive damages & external & 17,2 \\
\hline $\begin{array}{l}\text { Revenue from paid-activity of the third } \\
\text { sector (excluding businesses) }\end{array}$ & internal & 18,2 \\
\hline
\end{tabular}

Source: own analysis on the basis of a survey data of the Klon/Jawor Association research on "Condition of the third sector in Poland in 2015"; calculations run in STATSTICA 12.

Certainly, social enterprises (NGOs conducting a business activity) indicate the "penetration" of internal and external financing sources and, at the same time, public and private, while among NGOs that do not conduct a business activity a clearer division is visible - a bigger stress is put to external public financing.

\section{Conclusions}

Basing on the carried-out analysis, it seems legitimate to conclude as follows:

a) social enterprises run their operations on a statistically significantly bigger scale than non-earning NGOs; 
b) social enterprises indicate statistically significantly bigger involvement in finance from private sources of funding (interests, profits from endowment capital, deposits, shares and stocks and revenue from property) compared to non-earning organisations;

c) revenues from business activity (sale of goods and services) influence the operational scale of social enterprises the least;

d) social enterprises present the "penetration" of public and private financing sources (as well as external and internal) in the structure of sources of funding, which cannot be said about non-earning entities;

e) in both examined groups of entities - the EU funds mostly influence their scale of activity.

\section{Literature}

Brandstetter, L., Lehner, O. M. (2014). Impact Investment Portfolios: Including Social Risks and Returns. Oxford, UK: ACRN, Oxford Publishing House.

Çalışkan, K., Callon, M. (2009). Economization, part 1: Shifting Attention from the Economy towards Processes of Economization. Economy and Society, 38 (3), 369-398.

Carmin, J. (2010). NGO Capacity and Environmental Governance in Central and Eastern Europe. Acta Politica, $45(1-2), 183-202$.

Carroll, D.A., Stater, K.J. (2009). Revenue Diversification in Nonprofit Organizations: Does it Lead to Financial Stability? Journal of Public Administration Research and Theory, 19 (4), 947-966.

Chang, C.F., Tuckman, H.P. (1994). Revenue Diversification among Nonprofits. Voluntas: International Journal of Voluntary and Nonprofit Organizations, 5 (3), 273-290.

Dart, R. (2004a). Being “Business-like” in a Nonprofit Organization: A Grounded and Inductive Typology. Non-profit and Voluntary Sector Quarterly, 33, 290-310.

Dart, R. (2004b). The Legitimacy of Social Enterprise. Nonprofit Management \& Leadership, 14, 411-424.

Dees, J.G. (1998). Enterprising Nonprofits. Harvard Business Review, 76, 54-69.

Edwards, M., Hulme, D. (1996). Too Close For Comfort? The Impact of Official Aid on Nongovernmental Organizations, World Development, 24 (6), 961-973.

Eikenberry, A.M., Kluver, J.D. (2004). The Marketization of the Nonprofit Sector: Civil Society at Risk? Public Administration Review, 64 (2), 132-140.

Enjolras, B. (2002). The Commercialization of Voluntary Sport Organizations in Norway. Nonprofit and Voluntary Sector Quarterly, 31 (3), 352-376.

Froelich, K.A. (1999). Diversification of Revenue Strategies: Evolving Resource Dependence in Nonprofit Organizations. Nonprofit and Voluntary Sector Quarterly, 28 (3), 246-268.

Geobey, S., Weber, O. (2013). Lessons in Operationalizing Social Finance: The Case of Vancouver City Savings Credit Union. Journal of Sustainable Finance \& Investment, 3 (2), 124-137.

Gray, R., Bebbington, J., Collison, D. (2006). NGOs, Civil Society and Accountability: Making the People Accountable to Capital. Accounting, Auditing \& Accountability Journal, 19 (3), 319-348.

Greenlee, J., Trussel J. (2000). Estimating the Financial Vulnerability of Charitable Organizations. Nonprofit Management and Leadership, 11 (2), 199-210.

Hager, M. (2001). Financial Vulnerability among Arts Organizations: A Test of the Tuckman-Chang Measures. Nonprofit and Voluntary Sector Quarterly, 30 (2), 376-392.

http://fakty.ngo.pl/files/wiadomosci.ngo.pl/public/civicpedia/KondycjaNGO2015.pdf (20.03.2017). 
Keating, E., Fischer, M., Gordon, T., Greenlee, J. (2005). Assessing Financial Vulnerability in the Nonprofit Sector. Hauser Center for Nonprofit Organizations, Harvard University Working Paper.

Kerlin, J.A., Pollak, T. (2006). Nonprofit Commercial Revenue: A Replacement for Declining Government Grants and Private Contributions? Paper presented at the Third Annual, United Kingdom.

Kilby, P. (2006). Accountability for Empowerment: Dilemmas Facing Non-governmental Organizations. World Development, 34 (6), 951-963.

King, S. (2006). Pink Ribbons, Inc.: Breast Cancer and the Politics of Philanthropy. London: Minneapolis University of Minnesota Press, Kingdom Social Enterprise Research Conference.

Maier, F., Meyer, M., Steinbereithner, M. (2016). Nonprofit Organizations Becoming Business-Like a Systematic Review. Nonprofit and Voluntary Sector Quarterly, 45 (1), 64-86.

Martens, K. (2002). Mission Impossible? Defining Nongovernmental Organizations. Voluntas: International Journal of Voluntary and Nonprofit Organizations, 13 (3), 271-285.

Mikołajczak, P., Czternasty, W. (2015a). Social Enterprises versus Globalisation. Intercathedra, 31 (2), $43-52$.

Mikołajczak, P., Czternasty, W. (2015b). Wspieranie rozwoju przedsiębiorstw ekonomii społecznej w Polsce przez fundusze europejskie. Zeszyty Naukowe Uniwersytetu Szczecińskiego. Ekonomiczne Problemy Ustug, 116, $420-432$.

O’Donohoe, N., Leijonhufvud, C., Saltuk, Y., Bugg-Levine, A., Brandenburg, M. (2010). Impact Investments: An Emerging Asset Class. London: Morgan Global Research.

Salamon, L.M. (1987). Of Market Failure, Voluntary Failure, and Third-party Government: The Theory of Government-nonprofit Relations in the Modern Welfare State. Journal of Voluntary Action \& Research, 16, 29-49.

Salamon, L.M. (1995). Partners in Public Service: Government-nonprofit Relations in the Modern Welfare State. Baltimore: JHU Press.

Salamon, L.M., Hems, L.C., Chinnock, K. (2000). The Non-profit Sector: For What and for Whom? Working Papers of the The Johns Hopkins Comparative Non-profit Sector Project, 37.

Simpson, M., Cheney, G. (2007). Marketization, Participation, and Communication within New Zealand Retirement Villages: A Critical-rhetorical and Discursive Analysis. Discourse \& Communication, 1, 191-222.

Weber, O. (2012). Social Finance and Impact Investing. Retrived from: http://ssrn.com/abstract=2160403 (20.03.2017).

\section{ZNACZENIE ŹRÓDEL FINANSOWANIA DLA SKALI DZIALALNOŚCI PRZEDSIĘBIORSTW SPOLECZNYCH}

Streszczenie: W ciągu ostatnich kilku dekad w sektorze organizacji pozarządowych można zaobserwować istotne zmiany. Polegają one na adaptacji przez nie przedsiębiorczych zachowań, u której podstawy leży między innymi zapewnienie NGOs stabilności finansowej oraz możliwości sprawniejszej realizacji misji społecznej. Proces ten określa się najczęściej mianem ekonomizacji organizacji non-profit i wzbudza on wiele kontrowersji wśród licznych badaczy. Stał się zarazem impulsem dla rozwoju przedsiębiorstw społecznych jako podmiotów realizujących działalność gospodarczą nie dla maksymalizacji zysku, lecz w celu wypełniania zadań w sferze społecznej. Ich realizacja oprócz działalności zarobkowej wymaga wielu różnych źródeł wsparcia, które warunkują skalę ich oddziaływania społecznego.

$\mathrm{Cel}$ - celem artykułu jest analiza porównawcza wpływu poszczególnych źródeł finansowych na skalę działalności NGOs prowadzących działalność gospodarczą ( $\mathrm{tj}$. przedsiębiorstw społecznych) oraz nieprowadzących takiej aktywności.

Metodologia badania - do osiągnięcia tak postawionego celu posłużono się analizą ANOVA oraz rangowania. Skorzystano również z metod realizujących zadania regresyjne, w tym: regresji krokowej, drzew interakcyjnych (C\&RT), wzmacnianych drzew, MARSplines oraz sieci neuronowych.

Wynik - skala działalności przedsiębiorstw społecznych (NGOs prowadzących komercyjną sprzedaż produktów i usług) jest statystycznie istotnie wyższa niż niezarobkujących. Przedsiębiorstwa społeczne wykazują także większe zaangażowanie w wykorzystaniu źródeł prywatnych. Głównym źródłem przychodów determinujących skalę działalności NGOs zarobkujących i niezarobkujących są fundusze europejskie. 
Oryginalność/wartość - artykuł może stanowić istotny wkład w międzynarodową dyskusję poświęconą efektom ekonomizacji organizacji non-profit rozumianej jako komercyjna sprzedaż produktów i usług. Uwidacznia się bowiem niewielka liczba opracowań opartych na badaniach empirycznych, ukazujących rzeczywisty wpływ źródeł przychodów na skalę działalności przedsiębiorstw społecznych.

Słowa kluczowe: przedsiębiorstwa społeczne, NGOs, ekonomizacja, źródła finansowania Kody klasyfikacji JEL: M14, L31, L32

\section{Cytowanie}

Mikołajczak, P. (2017). The Importance of Funding Sources to the Scale of Activity of Social Enterprises. Finanse, Rynki Finansowe, Ubezpieczenia, 4 (88/2), s. 135-144. DOI: 10.18276/frfu.2017.88/2-14. 